\title{
WOLNOŚĆ SUMIENIA I WYZNANIA CUDZOZIEMCÓW W PRAWIE POLSKIM
}

\section{WPROWADZENIE}

Rozwój, szczególnie po II wojnie światowej, międzynarodowej ochrony praw człowieka, wzrost międzynarodowego przepływu osób w warunkach coraz lepszych i zróżnicowanych środków komunikacji, a zarazem członkostwo Rzeczypospolitej Polskiej w Unii Europejskiej od 1 maja 2004 r. czynią zasadną refleksję nad gwarancjami w prawie polskim dla cudzoziemców w zakresie wolności sumienia i wyznania ${ }^{1}$. Jest to tym bardziej zagadnienie godne refleksji, że wolność ta dotyczy najbardziej intymnej sfery ludzkiej osobowości, mającej wpływ na całokształt bytu indywidualnego i kolektywnego jednostki. Ponadto, zarówno w przeszłości, jak i współcześnie, dążenie jednostek i grup ludzkich do zapewnienia elementarnej swobody w sprawach religijnych to jeden $\mathrm{z}$ istotniejszych motywów migracji zagranicznych ${ }^{2}$.

* Dr, hab. Wydział Prawa i Administracji, Uniwersytet Warszawski, ul. Krakowskie Przedmieście 26/28, 00-927 Warszawa, e-mail: pawelborecki@op.pl

${ }^{1}$ Autor przyjmuje szeroką interpretację wolności sumienia i wyznania - zob. M. Pietrzak, Prawo wyznaniowe, Warszawa 2013, s. 34-38.

${ }^{2}$ Polska, pomimo członkostwa w Unii Europejskiej i związanego między innymi z tym faktem wzrostu dochodu narodowego, wciąż nie jest krajem migracyjnym (przyjmującym). Według Narodowego Spisu Ludności i Mieszkań z 2011 r. wśród stałych mieszkańców Polski 99,7\% stanowili obywatele polscy (38 401 tys.), 0,2\% - cudzoziemcy (63 tys.), nie ustalono obywatelstwa w $0,1 \%$ badanych. W porównaniu z badaniami z $2002 \mathrm{r}$. oznacza to dwukrotny wzrost odsetka cudzoziemców stale zamieszkujących w Polsce; zob. Główny 
Konstytucja Rzeczypospolitej Polskiej z dnia 2 kwietnia 1997 r. ${ }^{3}$ nie definiuje wprost pojęcia cudzoziemca. Jednak z jej art. 37 ust. 2 wynika pośrednio, że należy nim objąć osoby fizyczne niemające obywatelstwa polskiego, czyli zarówno będące obywatelami innych państw, jak $\mathrm{i}$ te nieposiadające żadnego obywatelstwa (apatrydzi, bezpaństwowcy). Opisaną interpretację przyjmuje ustawa z dnia 12 grudnia 2013 r. o cudzoziemcach ${ }^{4}$ (art. 3 pkt 2), lecz jedynie na potrzeby tego aktu normatywnego. Do tej wykładni odsyła także ustawa o udzielaniu cudzoziemcom ochrony na terytorium Rzeczypospolitej Polskiej (art. 2 pkt 4) $)^{5}$. Takie ujęcie rzeczonego pojęcia wydaje się optymalne dla rozważań dotyczących wolności i praw jednostki. Polskie prawo nie określa wszakże w pełni jednolicie pojęcia cudzoziemca. Jego najszerszy zakres zawiera ustawa z dnia 24 marca 1920 r. o nabywaniu nieruchomości przez cudzoziemców ${ }^{6}$. Obejmuje ono zarówno osoby fizyczne, jak i jednostki organizacyjne, przede wszystkim osoby prawne. Natomiast ustawa z dnia 17 maja 1989 r. o gwarancjach wolności sumienia i wyznania ${ }^{7}$ przyjmuje węższą wykładnię. Poza kategorią obywateli polskich wyróżnia także cudzoziemców i bezpaństwowców. Zapewnia im jednak taki sam zakres uprawnień (art. 7 ust. 1 i 2). Grupą, którą

Urząd Statystyczny, Wyniki Narodowego Spisu Powszechnego Ludności i Mieszkań 2011. Podstawowe informacje o sytuacji demograficzno-społecznej ludności Polski oraz zasobach mieszkaniowych, Warszawa 2012, s. 15-16.

${ }^{3}$ Dz. U. Nr 78, poz. 483 z późn. zm.

${ }^{4}$ Zgodnie z art. 1 ust. 2 i 3 ustawy z 1920 r., cudzoziemcem w rozumieniu tej ustawy jest: 1) osoba fizyczna nieposiadająca obywatelstwa polskiego; 2) osoba prawna mająca siedzibę za granicą; 3) nieposiadająca osobowości prawnej spółka osób wymienionych w pkt 1 lub 2, mająca siedzibę za granicą, utworzona zgodnie z ustawodawstwem państw obcych; 4) osoba prawna i spółka handlowa nieposiadająca osobowości prawnej mająca siedzibę na terytorium Rzeczypospolitej Polskiej, kontrolowana bezpośrednio lub pośrednio przez osoby lub spółki wymienione w pkt 1, 2 i 3. W przypadku spółki handlowej za kontrolowaną, w rozumieniu ustawy, uważa się spółkę, w której cudzoziemiec lub cudzoziemcy dysponują bezpośrednio lub pośrednio powyżej 50\% głosów na zgromadzeniu wspólników lub na walnym zgromadzeniu, także jako zastawnik, użytkownik lub na podstawie porozumień $\mathrm{z}$ innymi osobami, albo mają pozycję dominującą w rozumieniu przepisów art. 4 § 1 pkt 4 lit. b lub c, lub e ustawy z dnia 15 września 2000 r. - Kodeks spółek handlowych (Dz. U. Nr 94, poz. 1037, z 2001 r. Nr 102, poz. 1117 oraz z 2003 r. Nr 49, poz. 408 i Nr 229, poz. 2276)

${ }^{5}$ Tekst jedn. Dz. U. z 2012 r., poz. 680 z późn. zm.

${ }^{6}$ Tekst jedn. Dz. U. z 2004 r. Nr 167, poz. 1758 z późn. zm.

${ }^{7}$ Tekst jedn. Dz. U. z 2005 r. Nr 231, poz. 1965 z późn. zm. 
ustawodawca polski wyodrębnił w ramach cudzoziemców są obywatele Unii Europejskiej. Kryterium wspomniane okazuje się jednak istotne w dziedzinie zapewnienia wolności sumienia i wyznania.

\section{KONSTYTUCYJNE GWARANCJE WOLNOŚCI SUMIENIA I WYZNANIA CUDZOZIEMCÓW}

Ustawa zasadnicza z 1997 r. dąży do zapewnienia cudzoziemcom zakresu wolności i praw możliwie zbliżonego do tego, z którego korzystają obywatele polscy. Zgodnie z art. 37 ust. 1 tego aktu, każdy, kto znajduje się pod władzą państwa polskiego, korzysta z wolności i praw zapewnionych w Konstytucji. Zasada rzeczona dotyczy nie tylko jednostek znajdujących się na terytorium polskim, lecz także na pokładach polskich statków powietrznych i morskich, a nawet na terenie polskich misji dyplomatycznych i konsularnych, korzystających z przywileju nietykalności ${ }^{8}$. Dyskusyjne jest natomiast, czy omawiana zasada winna być stosowana na terenie polskich misji wojskowych za granicą. W korelacji z art. 37 ust. 1 Konstytucji pozostają ogólne postanowienia jej art. 32 ust. 1 i 2 stanowiące, że wszyscy są wobec prawa równi; wszyscy mają prawa do równego traktowania przez władze publiczne. W związku z tym nikt nie może być dyskryminowany w życiu politycznym, społecznym i gospodarczym z jakiejkolwiek przyczyny. Zarazem ustrojodawca w art. 37 ust. 2 wyraźnie dopuścił w odniesieniu do cudzoziemców możliwość wprowadzenia w drodze ustawy wyjątków od zasady egalitaryzmu w korzystaniu z konstytucyjnych wolności i praw przez osoby pozostające pod władzą Rzeczypospolitej Polskiej. Ograniczenia te muszą jednak być zgodne z wymogami art. 31 ust. 3 Konstytucji. Muszą zatem być ustanawiane tylko w ustawie i zaistnieć tylko wtedy, gdy są konieczne w demokratycznym państwie dla jego bezpieczeństwa lub porządku publicznego, bądź dla ochrony środowiska, zdrowia i moralności publicznej, albo wolności i praw innych osób. Ponadto ograniczenia te nie mogą naruszać istoty wolności i praw.

${ }^{8}$ Zob. W. Góralczyk, S. Sawicki, Prawo międzynarodowe publiczne w zarysie, Warszawa 2013, s. 274 i 282. 
W przypadku ograniczenia wolności uzewnętrzniania religii przez cudzoziemca przesłanki ewentualnych ograniczeń zostały sformułowane łagodniej. Winny być one bowiem ustanowione w drodze ustawy oraz konieczne do ochrony bezpieczeństwa państwa, porządku publicznego, zdrowia, moralności lub wolności i praw innych osób (art. 53 ust. 5 Konstytucji).

Współczesny polski ustrojodawca określając zakres podmiotowy wolności sumienia i wyznania zrezygnował z ograniczeń w oparciu o kryterium obywatelstwa. Zarówno wolność sumienia i religii (art. 53 ust. 1), wolność wyrażania poglądów (art. 54 ust. 1), jak i swoboda wyrażania przekonań religijnych, światopoglądowych i filozoficznych w życiu publicznym (art. 25 ust. 2) zostały odniesione do jednostki jako takiej ${ }^{9}$. Szczegółowe gwarancje konstytucyjne w dziedzinie wolności sumienia i wyznania dotyczące: dzieci (art. 48 ust. 1), wolności religii (art. 53 ust. 2), prawa rodziców do zapewnienia dzieciom wychowania religijnego i moralnego zgodnego ze swoimi przekonaniami (art. 53 ust. 3), zakazu zmuszania do uczestniczenia, ani do nieuczestniczenia w praktykach religijnych (art. 53 ust. 6), czy tzw. prawa do milczenia w sprawach religijno-światopoglądowych (art. 53 ust. 7) nie zostały przez Konstytucję ograniczone na podstawie przynależności państwowej. Pozornym wyjątkiem od zasady równych konstytucyjnych gwarancji wolności sumienia jest dopuszczenie przez ustrojodawcę tzw. sprzeciwu sumienia jedynie wobec obywateli w zakresie obowiązku służby wojskowej. Zgodnie $\mathrm{z}$ art. 85 ust. 3 Konstytucji, obywatel, któremu przekonania religijne lub wyznawane zasady moralne nie pozwalają na odbywanie służby wojskowej, może być obowiązany do służby zastępczej na zasadach określonych w ustawie ${ }^{10}$. Obowiązek służby wojskowej stanowi pierwszorzędny aspekt konstytucyjnego obowiązku obrony Ojczyzny, ciążącego jednak wyłącznie na obywatelach polskich, a nie na cudzoziemcach ${ }^{11}$.

${ }^{9}$ W szczególności w art. 53 ust. 1 i art. 54 ust. 1 Konstytucji użyto zaimka: „Każdemu”.

${ }^{10}$ Zob. ustawa z dnia 28 listopada 2003 r. o służbie zastępczej (tekst jedn. Dz. U. z 2014 r., poz. 1027).

${ }^{11}$ Inną konieczną przesłanką podlegania przez obywatela polskiego obowiązkowi obrony Ojczyzny jest posiadanie stałego miejsca zamieszkania na terenie Polski, zob. art. 4 ust. 1 ustawy z dnia 21 listopada 1967 r. o powszechnym obowiązku obrony Rzeczypospolitej Polskiej (tekst jedn. Dz. U. z 2012 r., poz. 461 z późn. zm.). 
Przyczyn odrzucenia w Konstytucji z 1997 r. kryterium politycznego, tzn. przesłanki obywatelstwa, w zakresie limitowania wolności sumienia i wyznania należy upatrywać przede wszystkim w przyjęciu przez ustrojodawcę prawnonaturalnej koncepcji wolności i praw człowieka i obywatela. Zgodnie z art. 30 ust. 1, jako źródło owych wolności i praw została uznana przyrodzona i niezbywalna godność człowieka, przysługująca zatem w równym stopniu każdej jednostce. Drugą przyczyną jest zapewne oddziaływanie międzynarodowych regulacji w dziedzinie wolności i praw człowieka. Ustawy konstytucyjne z 1921 r. ${ }^{12}$ i z 1935 r. ${ }^{13}$, a także Konstytucja Polskiej Rzeczypospolitej Ludowej ${ }^{14}$ ujmowały wolność sumienia i wyznania jako swobodę obywatelską. Jawiła się ona jako pochodząca z nadania państwa i możliwa do limitowania przez nie na podstawie przesłanek politycznych $^{15}$. Ustawodawca w ustawie z dnia 17 maja 1989 r. o gwarancjach wolności sumienia i wyznania, pragnąc pozostać formalnie w zgodzie z konstytucją z 1952 r., głównym podmiotem wolności sumienia i wyznania uczynił obywatela, by w dalszej części regulacji rzeczoną swobodą objąć cudzoziemców i bezpaństwowców. Zarazem w preambule wspomnianej ustawy odwołano się do międzynarodowych aktów prawnych $\mathrm{w}$ zakresie ochrony wolności $\mathrm{w}$ sprawach religijnych: Powszechnej Deklaracji Praw Człowieka ${ }^{16}$, Międzynarodowego Paktu Praw Obywatelskich i Politycznych ${ }^{17}$, Aktu Końcowego Konferencji Bezpieczeństwa i Współpracy w Europie (KBWE) ${ }^{18}$, czy Deklaracji Organizacji Narodów Zjednoczonych o wyeliminowaniu wszelkich form dyskryminacji z powodów religijnych i przekonań ${ }^{19}$.

Należy zwrócić uwagę, że Konstytucja, charakteryzując status związków wyznaniowych $\mathrm{i}$ ich relacje z państwem, nie różnicuje tej

${ }^{12}$ Zob. art. 111 ustawy konstytucyjnej z dnia 17 marca 1921 r. (Dz. U. Nr 44, poz. 267).

${ }^{13}$ Zob. art. 81 ust. 2 ustawy konstytucyjnej z dnia 23 kwietnia 1935 r. (Dz. U. Nr 30, poz. 227).

${ }^{14}$ Zob. art. 70 ust. 1 Konstytucji PRL z dnia 22 lipca 1952 r. (Dz. U. Nr 33, poz. 232).

${ }^{15}$ Zob. J. Krukowski, Kościól i Państwo. Podstawy relacji prawnych, Lublin 2000, s. 77.

${ }^{16}$ Zob. Wolność religii. Wybór materiatów. Dokumenty. Orzecznictwo, tłum. i oprac. T. Jasudowicz, Toruń 2001, s. 66-67.

${ }^{17}$ Dz. U. z 1977 r. Nr 38, poz. 167.

${ }^{18}$ Zob. Wolność religii, s. 117-118.

${ }^{19}$ Zob. tamże, s. 77-80. 
kategorii korporacji. Wyjątkiem jest jedynie prawo do nauczania religii w szkole, które przysługuje związkom wyznaniowym o uregulowanej sytuacji prawnej (art. 53 ust. 4). Ustrojodawca nie różnicuje jednak uprawnień związków wyznaniowych w oparciu o przesłankę przynależności etnicznej lub państwowej jej założycieli czy wyznawców. Co więcej, podkreśla w art. 25 ust. 1 równouprawnienie kościołów i innych związków wyznaniowych ${ }^{20}$. Zatem brak jest konstytucyjnych przesłanek, aby deprecjonować status zagranicznych związków wyznaniowych, skupiających cudzoziemców, podejmujących działalność w Polsce, w porównaniu ze wspólnotami religijnymi o charakterze krajowym, obejmującymi obywateli polskich. Należy jednak podkreślić, że związki wyznaniowe jako forma realizacji kolektywnej wolności uzewnętrzniania religii, mogą być ograniczane w oparciu o przesłanki wskazane w art. 53 ust. 5 w związku z art. 25 ust. 1 i art. 32 ust. 1 i 2 Konstytucji.

Ograniczenia wolności sumienia i wyznania cudzoziemców, tak jak i obywateli polskich, wiążą się z przyjęciem w art. 53 Konstytucji zawężającej koncepcji wolności sumienia i religii oraz z mniejszymi gwarancjami wolności sumienia i wyznania dla osób niewierzących. W ujęciu polskiego ustrojodawcy, wolność sumienia i religii nie obejmuje swym zakresem przekonań światopoglądowych o charakterze ateistycznym czy agnostycznym. Wolność religii obejmuje formy enumeratywnie wymienione w art. 53 ust. 2 Konstytucji, charakterystyczne przede wszystkim dla religii tradycyjnych. Należy to oceniać jako niedoskonałość legislacyjną. Zgodnie z tym przepisem, rzeczona wolność obejmuje wolność wyznawania lub przyjmowania religii według własnego wyboru oraz uzewnętrzniania indywidualnie lub

${ }^{20} \mathrm{Na}$ temat wykładni konstytucyjnej zasady równouprawnienia związków wyznaniowych zob.: J. Szymanek, Konstytucyjna zasada równouprawnienia kościołów i innych związków wyznaniowych, „Studia Prawnicze” [PAN] 2009, z. 1-2, s. 161-175; P. Borecki, Zasada równouprawnienia wyznań w prawie polskim, „Studia z Prawa Wyznaniowego" 2007, t. 10, s. 115-159. Krytyka wykładni wspomnianej zasady w ujęciu Trybunału Konstytucyjnego zob. P. Borecki, M. Pietrzak, Glosa do wyroku Trybunatu Konstytucyjnego z 2 IV 2003 r., K 13/02, „Państwo i Prawo” 2003, z. 8, s. 119-124 i W. Brzozowski, Glosa do wyroku Trybunału Konstytucyjnego z 14 XII 2009, K 55/07, „Państwo i Prawo” 2010, z. 5, s. 126-131. 
z innymi, publicznie lub prywatnie, swojej religii przez uprawianie kultu, modlitwę, uczestniczenie w obrzędach, praktykowanie i nauczanie. Wolność religii obejmuje także posiadanie świątyń i innych miejsc kultu w zależności od potrzeb ludzi wierzących oraz prawo osób do korzystania z pomocy religijnej tam, gdzie się znajdują. Jest znamienne, że dopuszcza się wolność przyjmowania religii, ale nie przewiduje się szerszej wolności zmiany religii, w tym wolności przyjęcia światopoglądu niereligijnego. Paradoksalnie przybliża to Polskę bardziej do standardów państw muzułmańskich, w których odstępstwo od islamu jest karalne, niż do wymogów wynikających z art. 9 ust. 1 Konwencji o Ochronie Praw Człowieka i Podstawowych Wolności z 1950 r. Brak jest w Konstytucji analogicznych szczegółowych gwarancji wolności wyrażania światopoglądu niereligijnego ${ }^{21}$. Nie przewiduje się możliwości jego nauczania w szkołach. Ustawodawca milczy na temat bezwyznaniowości, światopoglądu laickiego czy humanistycznego. Nie zaskakuje zatem, że w ustawie zasadniczej pominięto kategorię laickich organizacji światopoglądowych. Osoby niewierzące (w tym cudzoziemcy) mogą na podstawie Konstytucji z 1997 r. dochodzić swych uprawnień w dziedzinie wolności sumienia i wyznania poprzez swoistą wykładnię wolności wyrażania poglądów (art. 54 ust. 1), która gwarantowana jest jednak w kontekście wolności środków masowego przekazu, a także odwołując się do nierozwiniętych przez ustrojodawcę pojęć: wolność sumienia i wyznania (art. 48 ust. 1) czy swoboda wyrażania przekonań religijnych światopoglądowych i filozoficznych (art. 25 ust. 2). Z wymienionych pojęć można dopiero próbować wyinterpretować szczegółowe uprawnienia, przede wszystkim indywidualne, przysługujące osobom bezwyznaniowym. Zarazem nieuprawnione jest $\mathrm{w}$ świetle prawa polskiego przyjęcie rozszerzającej, funkcjonalnej, definicji religii i tym samym rozszerzenie konstytucyjnej ochrony przysługującej osobom wierzącym na wyznawców światopoglądu niereligijnego. Współczesny polski ustawodawca nie sformułował odpowiedniej definicji legalnej. Konstytucja RP z 1997 r. w świetle treści zwłaszcza art. 53 ust. 2 skłania się ku wąskiemu ujęciu

${ }^{21}$ Szerzej nt. sytuacji osób bezwyznaniowych w prawie polskim zob. P. Borecki, Status prawny osób bezwyznaniowych w Polsce, „Państwo i Prawo” 2007, z. 4, s. 16-30. 
religii, związanemu z tradycyjnymi dla Polski formami religijności. Religia powiązana zostaje $\mathrm{z}$ takimi zjawiskami jak: modlitwa, obrzędy, kult, świątynie. W preambule konstytucyjnej definicja Boga jako źródła prawdy, sprawiedliwości, dobra i piękna wyraźnie nosi znamię chrześcijańskie. Podobnie, ku tzw. klasycznej definicji religii, zorientowane jest orzecznictwo Naczelnego Sądu Administracyjnego. W wyroku z dnia 23 stycznia 1998 r. (sygn. akt I SA 1065/97) NSA stwierdził, że „Religia jest powiązaniem między człowiekiem a Bogiem, inaczej mówiąc - relacją między człowiekiem a świętością (sacrum). Zakłada aktywność osoby ludzkiej w dążeniu do świętości przez zbliżenie do Boga"22. Dla porównania, w systemie prawnym Stanów Zjednoczonych federalny Sąd Najwyższy w swoim orzecznictwie od kilku dziesięcioleci przyjmuje szeroką, fenomenologiczną koncepcję religii. Pozwala to objąć wspomnianym pojęciem takie przekonania czy wierzenia, jak buddyzm, taoizm, kultura etyczna czy świecki humanizm ${ }^{23}$.

\section{OCHRONA WOLNOŚCI SUMIENIA I WYZNANIA CUDZOZIEMCÓW} W AKTACH PRAWA MIĘDZYNARODOWEGO PRZYJĘTYCH PRZEZ POLSKĘ

W dziedzinie aktów prawa międzynarodowego Polska ratyfikowała i włączyła do swojego porządku prawnego najważniejsze uniwersalne i regionalne umowy międzynarodowe gwarantujące wolności i prawa człowieka, w tym szeroko rozumianą wolność sumienia i wyznania. Międzynarodowy Pakt Praw Obywatelskich i Politycznych ONZ z 1966 r. (art. 18), Konwencja o Ochronie Praw Człowieka i Podstawowych Wolności (art. 9), Karta Praw Podstawowych Unii Europejskiej z 2000 r. (art. 10) 24, zapewniając wolność myśli, sumienia i wyznania (religii), definiują ją jako swobodę przysługującą każdej jednostce, działającej indywidualnie lub kolektywnie, bez względu na przyna-

22 „Orzecznictwo Naczelnego Sądu Administracyjnego” 1998, nr 4, poz. 135.

${ }^{23}$ Szerzej zob. M. Potz, Granice wolności religijnej. Kwestie wolności sumienia $i$ wyznania oraz stosunku państwa do religii w Stanach Zjednoczonych Ameryki, Wrocław 2008, s. 66-72.

${ }^{24}$ Dz. Urz. U. E. z 2010 r. C 83/389. 
leżność państwową. Wskazując aspekt podmiotowy gwarantowanej wolności, posłużono się określeniami ogólnymi, np.: „każda osoba” czy „nikt”. Równie szerokim ujęciem operują międzynarodowe akty prawne, których nasze państwo jest sygnatariuszem: Powszechna Deklaracja Praw Człowieka z 1948 r., Akt Końcowy KBWE z 1975 r., Deklaracja Organizacji Narodów Zjednoczonych o wyeliminowaniu wszelkich form dyskryminacji z powodów religijnych i przekonań z $1981 \mathrm{r}$.

Należy odnotować, że Międzynarodowy Pakt Praw Obywatelskich i Politycznych zapewnia lepszą ochronę poglądów w sprawach religijnych niż gwarancje zawarte w Konstytucji RP. Komitet Praw Człowieka ONZ dokonując wykładni terminów „,religia”, ,przekonania” zawartych w art. 18 Paktu stwierdził, iż ,mają być rozumiane szeroko. Art. 18 [Paktu Praw Obywatelskich i Politycznych ONZ - P.B.] w zastosowaniu swym nie ogranicza się do charakterystycznych cech instytucjonalnych czy do praktyk analogicznych do praktyk religii tradycyjnych"25. Także Europejski Trybunał Praw Człowieka (ETPCz) wielokrotnie konstatował, że art. 9 Konwencji z 1950 r. ma znaczenie także dla ateistów, agnostyków czy osób religijnie obojętnych. Ochronę wolności kolektywnej uzewnętrzniania światopoglądu niereligijnego za pośrednictwem organizacji laickich ETPCz zapewnia jednak na odmiennych zasadach niż ochronę wyznawania religii za pośrednictwem związków wyznaniowych.

Kryterium obywatelstwa jako konieczną przesłankę realizacji szczegółowego aspektu wolności sumienia i wyznania katolików piastowania godności biskupów w Polsce, wprowadziła partykularna umowa międzynarodowa - Konkordat między Stolicą Apostolską a Rzecząpospolitą Polską, podpisany 28 lipca 1993 r. $^{26}$, a ratyfikowany 23 lutego 1998 r. $^{27}$ Jedynie dla obywateli polskich zastrzeżono możliwość nominacji na godność biskupią przez Stolicę Apostolską (art. 7 ust. 3). Ponadto, biskup niebędący obywatelem polskim

${ }^{25}$ Komitet Praw Człowieka ONZ, Uwagi Ogólne nr 22 (48 dot. art. 18 przyjęte 20 lipca 1993 roku, w: Wolność religii, s. 70.

${ }^{26}$ Dz. U. z 1998 r. Nr 52, poz. 318.

${ }^{27}$ Traktat wszedł w życie miesiąc po wymianie dokumentów ratyfikacyjnych, czyli 25 kwietnia $1998 \mathrm{r}$. 
nie będzie należał do Konferencji Episkopatu Polski. Biskup taki nie będzie sprawował jurysdykcji w Rzeczypospolitej Polskiej, wyjąwszy legata lub innego wysłannika papieskiego (art. 6 ust. 5). Przewidując powyższe wyłączenie, traktat zabezpiecza Kościół przed ewentualnymi trudnościami w obsadzeniu jakiegoś urzędu kościelnego w Polsce, gdy zaszłaby konieczność powołania czasowego administratora ${ }^{28}$. Zarazem nie ma żadnych ograniczeń w zakresie obywatelstwa w odniesieniu do nuncjusza apostolskiego, bowiem jako legat papieski nie musi on posiadać obywatelstwa polskiego ${ }^{29}$. W sumie powyższe wymogi stanowią w istocie wyjątek od zasady niezależności Kościoła od państwa, wynikającej z art. 1 Konkordatu ${ }^{30}$. Jest to zatem również wyjątek od konstytucyjnej zasady niezależności państwa i związków wyznaniowych w swoim zakresie (art. 25 ust. 3). Ponadto, zakaz pełnienia godności biskupów przez cudzoziemców w Kościele katolickim w Polsce można oceniać jako sprzeczny z konstytucyjną zasadą równouprawnienia kościołów i innych związków wyznaniowych (art. 25 ust. 1). Należy natomiast podkreślić, że Konkordat z 1993 r. przewiduje całkowitą swobodę Kościoła w obsadzie innych stanowisk kościelnych w Polsce ${ }^{31}$.

We współczesnej Europie, w warunkach swobody przepływu osób w Unii Europejskiej i uznania przez ETPCz autonomii związków wyznaniowych w szczególności w dziedzinie obsady ich stanowisk wewnętrznych, tego rodzaju ograniczenia wydają się być anachronicz-

${ }^{28}$ J. Wisłocki, Konkordat polski 1993. Tak czy nie?, Poznań 1993, s. 125.

${ }^{29}$ Jako fenomen w praktyce dyplomacji Stolicy Apostolskiej należy ocenić pełnienie funkcji nuncjusza apostolskiego w Polsce przez obywatela polskiego, abp. Józefa Kowalczyka, i to wyjątkowo długo, tzn. w latach 1989-2010.

${ }^{30}$ Art. 1 Konkordatu z 1993 r. stanowi: „Rzeczpospolita Polska i Stolica Apostolska potwierdzają, że Państwo i Kościół Katolicki są każde - w swoim zakresie - niezależne i autonomiczne oraz zobowiązują się do pełnego poszanowania tej zasady we wzajemnych stosunkach i we współdziałaniu dla rozwoju człowieka i dobra wspólnego". Szerzej na temat zasady niezależności państwa i Kościoła zob. W. Góralski, A. Pieńdyk, Zasada niezależności i autonomii Państwa i Kościoła w konkordacie Polskim z 1993 roku, Warszawa 2000, s. 11-23.

${ }^{31} \mathrm{Za}$ uchylony wobec Kościoła katolickiego po wejściu w życie art. 7 Konkordatu z 1993 r., gwarantującego, że urzędy kościelne obsadza kompetentna władza kościelna zgodnie z przepisami prawa kanonicznego, należy uznać wymóg zawarty w art. 14 ust. 4 ustawy z dnia 17 maja 1989 r. o gwarancjach wolności sumienia i wyznania. 
ne. Świadczą o postrzeganiu liderów wspólnot religijnych, a zwłaszcza hierarchii katolickiej, jako czynnika politycznego, posiadającego wpływy w społeczeństwie. Dla porównania, konkordat z Portugalią z 2004 r. milczy na temat wymogów obywatelstwa w odniesieniu do nominatów na godności biskupie w tym kraju ${ }^{32}$. Wymóg obywatelstwa polskiego może wydawać się uzasadniony jedynie wobec osoby powołanej na stanowisko katolickiego ordynariusza w duszpasterstwie wojskowym. Do służby wojskowej zobowiązani są bowiem obywatele polscy, właściwe duszpasterstwo stanowi element składowy Ministerstwa Obrony Narodowej ${ }^{33}$. Osoba ordynariusza polowego winna dawać gwarancje lojalności wobec państwa, zwłaszcza z racji potencjalnego wpływu na żołnierzy wyznania katolickiego, czy prawdopodobnego dostępu do informacji niejawnych.

Istotnym brakiem w dziedzinie prawnomiędzynarodowej ochrony wolności sumienia i wyznania jest niepodpisanie i nieratyfikowanie przez Polskę Protokołu nr 12 do Konwencji o Ochronie Praw Człowieka i Podstawowych Wolności. Gwarantuje on w art. 1 ust. 1, że korzystanie $\mathrm{z}$ każdego prawa przewidzianego $\mathrm{w}$ prawie powinno być zapewnione bez dyskryminacji wynikającej z takich powodów, jak płeć, rasa, kolor skóry, język, religia, przekonania polityczne lub inne, pochodzenie narodowe lub społeczne, przynależność do mniejszości narodowej, majątek, urodzenie lub z jakichkolwiek innych przyczyn ${ }^{34}$. Cudzoziemcy nie mogą zatem obecnie korzystać z prawa do wniesienia skargi przeciwko państwu polskiemu do Europejskiego Trybunału Praw Człowieka pod zarzutem dyskryminacji na podstawie kryterium obywatelstwa w dziedzinie wolności myśli, sumienia i wyznania.

32 „Acta Apostolicae Sedis” 97(2005), s. 29-50.

${ }^{33}$ Zob. zarządzenie nr 72 Ministra Obrony Narodowej z dnia 6 kwietnia 1994 r. w sprawie organizacyjnego usytuowania Ordynariatu Polowego w resorcie obrony narodowej oraz współpracy organów wojskowych z Ordynariatem Polowym (Dz. Roz. MON z dnia 6 kwietnia 1994 r., poz. 28). W aktualnych warunkach ordynariusz polowy Wojska Polskiego ma potencjalnie szerokie wpływy w instytucjach państwowych. Jest bowiem także szefem duszpasterstwa katolickiego w innych ,strukturach siłowych” - w Straży Granicznej, w Policji, czy w Służbie Celnej.

${ }^{34} \mathrm{http}$ //www.ptpa.org.pl/public/files/akty_prawne/Protokol_nr_12_do_KwSLWFDK pdf [dostęp: 28.11.2014]. 
Polska zapewnia także słabsze gwarancje praw bezpaństwowcom ${ }^{35}$ niż zdecydowana większość państw Unii Europejskiej. Nie ratyfikowała bowiem najważniejszych aktów prawa międzynarodowego w tej dziedzinie - przede wszystkim Konwencji Dotyczącej Statusu Bezpaństwowców z 1954 r. W art. 4 tego aktu umawiające się państwa zobowiązały się przyznać „(...) bezpaństwowcom na swych terytoriach traktowanie przynajmniej tak korzystne jak traktowanie przyznane ich obywatelom odnośnie do wolności praktykowania ich religii, oraz wolności w dziedzinie religijnego wychowania dzieci (...)"36.

Ograniczenie ochrony wolności sumienia i wyznania dzieci w Polsce, zarówno mających status obywateli, jak i cudzoziemców, wiążą się z ratyfikacją Konwencji o Prawach Dziecka ONZ z 1989 r. ${ }^{37}$, ale przy załączeniu przez Rzeczpospolitą Polską m.in. ograniczającej deklaracji. W art. 14 ust. 1 i 2 umowy zobowiązano się respektować prawo dziecka do swobody myśli, sumienia i wyznania, a zarazem prawa i obowiązki rodziców (opiekunów prawnych) odnośnie do ukierunkowania dziecka w korzystaniu z jego prawa w sposób zgodny z rozwijającymi się zdolnościami dziecka ${ }^{38}$. Zarazem jednak państwo polskie oświadczyło, że wykonania przez dziecko jego praw określonych w Konwencji, w szczególności praw określonych w artykułach od 12 do 16, dokonuje się z poszanowaniem władzy rodzicielskiej, zgodnie z polskimi zwyczajami i tradycjami dotyczącymi miejsca dziecka $\mathrm{w}$ rodzinie i poza rodziną. Liberalne przepisy Konwencji o Prawach Dziecka, m.in. gwarantujące dzieciom wolność sumienia i wyznania, trzeba zatem interpretować w Polsce przez pryzmat deklaracji nakazującej uwzględnić polskie zwyczaje i tradycje, te zaś

${ }^{35}$ Wg danych GUS w 2011 r. w Polsce przebywało 8,8 tys. osób, których obywatelstwo nie było ustalone. Liczbę bezpaństwowców pod koniec 2013 r. szacowano na ok. 2 tys. osób; zob. szerzej: Polska zaniedbuje bezpaństwowców, http://prawo.rp.pl/artykul/1073994.html [dostęp: 29.11.2014].

${ }^{36}$ Wolność religii, s. 86. Polska nie przystąpiła również do Konwencji o Ograniczeniu Zjawiska Bezpaństwowości z $1961 \mathrm{r}$.

${ }^{37}$ Dz. U. z 1991 r. Nr 120, poz. 526.

${ }^{38}$ Zgodnie z art. 14 ust. 3 Konwencji, swoboda wyrażania wyznawanej religii lub przekonań może podlegać tylko takim ograniczeniom, które są przewidziane prawem i są konieczne do ochrony bezpieczeństwa narodowego i porządku publicznego, zdrowia lub moralności społecznej bądź podstawowych praw i wolności innych osób. 
mają charakter częstokroć restrykcyjny, naznaczony mizoginizmem i patriarchalizmem. Zostały one ukształtowane w dużej mierze przez katolicyzm. Polskie prawo krajowe zawiera niejednokrotnie słabsze gwarancje wolności sumienia i wyznania dzieci, niż systemy prawne szeregu państw europejskich.

\section{USTAWODAWSTWO POLSKIE A WOLNOŚĆ SUMIENIA I WYZNANIA CUDZOZIEMCÓW}

Najliczniejsze ograniczenia w dziedzinie wolności sumienia i wyznania na podstawie kryterium obywatelstwa występują w polskim systemie prawnym na szczeblu ustawowym. Dotyczą one przede wszystkim zajmowania przez cudzoziemców stanowisk kierowniczych w związkach wyznaniowych, członkostwa w tych korporacjach oraz ich rejestracji.

Wobec osób tej kategorii zakazy pełnienia pewnych funkcji kierowniczych w związkach wyznaniowych zawierają utrzymane w mocy

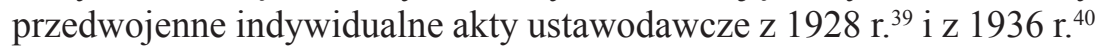
Owe ograniczenia są wyrazem ustrojowej koncepcji relacji między państwem a związkami wyznaniowymi wyrażonej w obu polskich ustawach konstytucyjnych rzeczonego okresu. Odzwierciedlały one system zwierzchnictwa wyznaniowego państwa nad związkami wyznaniowymi. Jego komponentem był nadzór państwa nad wspólnotami religijnymi, także w aspekcie personalnym. W okresie międzywojennym wymóg posiadania obywatelstwa polskiego znajdował pewne uzasadnienie w pełnieniu przez duchownych uznanych przez państwo związków wyznaniowych zadań funkcjonariuszy publicznych, np. w dziedzinie prowadzenia ksiąg stanu cywilnego i sporządza-

${ }^{39}$ Zob. rozporządzenie Prezydenta Rzeczypospolitej z dnia 22 marca 1928 r. o stosunku Państwa do Wschodniego Kościoła Staroobrzędowego, nie posiadającego hierarchii duchownej (Dz. U. Nr 38, poz. 363 z późn. zm.)

${ }^{40}$ Zob. ustawa z dnia 21 kwietnia 1936 r. o stosunku Państwa do Muzułmańskiego Związku Religijnego w Rzeczypospolitej Polskiej (Dz. U. Nr 30, poz. 230) oraz ustawa z dnia 21 kwietnia 1936 r. o stosunku Państwa do Karaimskiego Związku Religijnego w Rzeczypospolitej Polskiej (Dz. U. Nr 30, poz. 231 z późn. zm). 
nia stosownych aktów. Zgodnie z art. 5 rozporządzenia Prezydenta RP z 1928 r., członkowie Naczelnej Rady Staroobrzędowców zwłaszcza winni być obywatelami polskimi ${ }^{41}$. Wyraźnie bardziej restrykcyjne są ustawy z 1936 r. Prym wiedzie regulacja dotycząca Muzułmańskiego Związku Religijnego (MZR) w RP. Przewiduje ona bowiem generalnie, że piastowanie godności, stanowisk i urzędów, zarówno duchownych, jak i świeckich, a także korzystanie z biernego i czynnego prawa wyborczego zależy od posiadania obywatelstwa polskiego. W szczególności wymóg obywatelstwa polskiego dotyczy kandydatów na urząd Muftiego RP. W przypadku Karaimskiego Związku Religijnego w RP, kryterium posiadania obywatelstwa polskiego dotyczy duchownych, godności, stanowisk i urzędów oraz stanowi przesłankę konieczną biernego i czynnego prawa wyborczego, lecz tylko w karaimskich gminach wyznaniowych.

Indywidualne ustawy wyznaniowe $\mathrm{z}$ lat 1989-1997 nie formułują bezpośrednich ograniczeń wobec cudzoziemców w zakresie pełnienia funkcji kierowniczych we właściwych związkach wyznaniowych. Jednak art. 14 ust. 4 ustawy z dnia 17 maja 1989 r. o gwarancjach wolności sumienia i wyznania stwierdza, że jeżeli odrębna ustawa lub ratyfikowana umowa międzynarodowa nie stanowią inaczej, przed objęciem przez cudzoziemca stanowisk w kierowniczych organach wykonawczych kościoła lub innego związku wyznaniowego lub w organach wykonawczych jednostek organizacyjnych szczebla diecezji lub parafii dany związek wyznaniowy winien upewnić się, czy minister właściwy do spraw wyznań religijnych nie wyraża wobec tego zastrzeżeń. Niezgłoszenie zastrzeżeń $\mathrm{w}$ terminie 60 dni od daty powiadomienia uważa się za wyrażenie zgody. Ustawodawca nie określił jednak nie tylko formy powiadomienia i ewentualnie formy zgłoszenia zastrzeżeń, ale przede wszystkim konsekwencji niedokonania przez związek wyznaniowy zgłoszenia faktu objęcia stanowiska kierowniczego przez cudzoziemca, a przede wszystkim następstw zgłoszenia zastrzeżeń wobec cudzoziemca przez właściwego ministra. Ustawodawca nie przewiduje w tym przypadku sankcji nieważności czy bezskuteczności. W sumie analizowany przepis to lex imperfecta. Organ rejestrowy

${ }^{41}$ Pozostałe wymogi to: ukończenie 21 lat oraz pełna zdolność do czynności prawnych. 
może jednak na podstawie art. 36 a ustawy o gwarancjach wolności sumienia podjąć próbę wystąpienia do sądu okręgowego o stwierdzenie niezgodności działania danego związku wyznaniowego z art. 27 ust. 1 rzeczonej ustawy, tzn. z przepisami ustawowymi chroniącymi bezpieczeństwo lub porządek publiczny. Wątpliwe jest jednak, aby niedopełnienie wspomnianego obowiązku informacyjnego, w szczególności - niemające charakteru częstego, mogło być uznane przez sąd za rażące naruszenie prawa, mogące skutkować tzw. delegalizacją związku wyznaniowego na podstawie art. 36 a ustawy z dnia 17 maja 1989 r. Według informacji uzyskanych w Departamencie Wyznań Religijnych oraz Mniejszości Narodowych i Etnicznych Ministerstwa Administracji i Cyfryzacji, związki wyznaniowe generalnie stosują się do opisanego obowiązku. Administracja wyznaniowa nie stosuje zarazem sankcji w przypadku braku stosownego powiadomienia. Od przynajmniej kilkunastu lat nie zdarzyło się, aby minister właściwy do spraw wyznań religijnych zgłosił zastrzeżenia do powołania cudzoziemca na stanowisko w związku wyznaniowym.

Ustawodawca polski ujawnia nieufność wobec cudzoziemców także jako inicjatorów związków wyznaniowych działających w Polsce. Zgodnie $\mathrm{z}$ art. 31 ust. 1 ustawy o gwarancjach wolności sumienia i wyznania, z wnioskiem do właściwego ministra o wpis wspólnoty religijnej do rejestru kościołów i innych związków wyznaniowych może wystąpić jedynie grupa co najmniej stu obywateli polskich posiadających pełną zdolność do czynności prawnych. Powyższy wymóg stanowi wyjątek do zasady wyrażonej w art. 7 ust. 1 i 2 wymienionej ustawy, zgodnie z którą cudzoziemcy, odpowiednio - bezpaństwowcy, przebywający na terytorium Rzeczypospolitej Polskiej korzystają z wolności sumienia i wyznania na równi z obywatelami polskimi. Z wnioskami mogą występować nawet obywatele polscy stale mieszkający zagranicą. Nie ma natomiast żadnych przeszkód formalnoprawnych dla wstąpienia cudzoziemców do już zarejestrowanych związków wyznaniowych. Restrykcyjny i dyskryminacyjny charakter wspomnianego ograniczenia uwypukla ustawa z dnia 7 kwietnia 1989 r. - Prawo o stowarzyszeniach, która w art. 4 ust. 1 dopuszcza tworzenie stowarzyszeń przez cudzoziemców zamieszkałych w Polsce. Co więcej, dopuszczalne jest założenie i funkcjonowanie stowarzyszenia skupia- 
jącego jedynie cudzoziemców lub też takiego, w którym z uwagi na wymogi statutowe cudzoziemcy stanowić będą większość. Reasumując, status członkowski cudzoziemców w stowarzyszeniach funkcjonujących w myśl Prawa o stowarzyszeniach jest identyczny, jak status obywateli polskich ${ }^{42}$.

Zasadny jest zatem postulat polegający na przyznaniu cudzoziemcom prawa występowania $\mathrm{z}$ wnioskami o wpis związków wyznaniowych do rejestru kościołów i innych związków wyznaniowych na równi z obywatelami polskimi. Jedynym nowym wymogiem, którego ustanowienie można byłoby rozważyć zarówno wobec cudzoziemców jak i obywateli polskich wnioskujących o rejestrację, to wymóg posiadania stałego miejsca zamieszkania na terenie Polski. Spełnienie owego kryterium uprawdopodabniałoby, że rejestrowany związek wyznaniowy, któremu prawo polskie przyznaje szereg uprawnień szczególnych, jest wspólnotą wyznaniową realnie działającą w naszym kraju, zwłaszcza zaspokajającą potrzeby religijne grupy jego ludności.

Szczególne ograniczenie członkostwa cudzoziemców we wspólnotach konfesyjnych zawiera ustawa z dnia 20 lutego 1997 r. o stosunku Państwa do gmin wyznaniowych żydowskich w Rzeczypospolitej Polskiej ${ }^{43}$. Przewiduje ona, że członkami gmin wyznaniowych żydowskich w RP mogą być jedynie pełnoletnie osoby wyznania mojżeszowego, posiadające obywatelstwo polskie i zamieszkałe na terytorium Polski (art. 2 ust. 1). Powyższe ograniczenie można interpretować jako przejaw obaw rodzimego ustawodawcy przed zdominowaniem nielicznej polskiej społeczności judaistycznej przez wpływowe zagraniczne środowiska wyznawców mozaizmu. Obawy te były o tyle aktualne, że ustawa z dnia 20 lutego 1997 r. przewidziała na rzecz gmin wyznaniowych żydowskich w RP, wchodzących w skład Związku Gmin Wyznaniowych Żydowskich (ZGWŻ) ograniczoną restytucję mienia nieruchomego. O podobnych obawach można mówić wewnątrz samego ZGWŻ - jego prawo wewnętrzne formułuje bowiem w zakresie członkostwa w gminach wyznaniowych żydowskich takie same kryteria, co ustawodawca. Wykładnia art. 2 ust. 1 i 2 ustawy z 1997 r. przewidującego

${ }^{42}$ P. Sarnecki, Prawo o stowarzyszeniach. Komentarz, Kraków 2007, s. 33.

${ }^{43}$ Dz. U. Nr 42, poz. 251 z późn. zm. 
obligatoryjne członkostwo gmin wyznaniowych żydowskich w ZGWŻ oraz wykluczającego przynależność do tych gmin cudzoziemców, a także obywateli polskich zamieszkałych zagranicą, może prowadzić do konkluzji, że wykluczona jest całkiem możliwość przynależności czy tworzenia przez cudzoziemców gmin wyznaniowych żydowskich w Polsce, jako pewnej tradycyjnej formy samoorganizacji wyznawców judaizmu. Nieprzyjęcie cudzoziemca do gminy wyznaniowej żydowskiej w praktyce zmniejsza dlań gwarancje prawne dla wykonywania niektórych uprawnień z zakresu wolności praktykowania religii, np. w zakresie zwolnienia od pracy lub nauki dla obchodzenia judaistycznych świąt religijnych. Paradoksalnie nie ma natomiast przeszkód formalnoprawnych, aby cudzoziemiec wyznania judaistycznego został wybrany na członka zarządu ZGWŻ czy gminy wyznaniowej żydowskiej, o ile prawo wewnętrzne tej wspólnoty religijnej tego nie wyklucza.

Natomiast w świetle art. 1 ustawy z 1936 r. o stosunku Państwa do MZR w RP, ograniczenia w dziedzinie członkostwa mają charakter inkluzywny. Do tegoż związku mają należeć w ogóle wyznawcy islamu na obszarze Polski, zarówno cudzoziemcy, jak i obywatele polscy, niezależnie od tego, jaki nurt doktrynalny islamu reprezentują. W świetle ustawy, MZR ma charakter korporacji przymusowej, a zarazem w ramach islamu w Polsce - uniwersalnej. Cudzoziemcy zostali jednak pozbawieni w MZR praw wyborczych.

Powyższe ograniczenia uprawnień cudzoziemców w dziedzinie pełnienia funkcji kierowniczych w związkach wyznaniowych są zapewne sprzeczne z zasadą niezależności związków wyznaniowych od państwa (art. 25 ust. 3 Konstytucji). To same związki wyznaniowe powinny decydować o ewentualnym limitowaniu uprawnień swoich członków na podstawie kryterium obywatelstwa. Opisane ograniczenie nie znajduje uzasadnienia w powierzeniu kierownikom związków wyznaniowych funkcji w zastępstwie państwa. Jedynie 11 Kościołów i związków wyznaniowych ma prawo udzielania tzw. ślubów wyznaniowych ze skutkami cywilnymi ${ }^{44}$. Właściwi duchowni pełnią funkcje

${ }^{44}$ Są to: Kościół Katolicki, Polski Autokefaliczny Kościół Prawosławny, Kościół Ewangelicko-Augsburski w RP, Kościół Ewangelicko-Reformowany w RP, Kościół 
urzędników stanu cywilnego w ograniczonym zakresie i w praktyce rzadko wykonują ją osoby pełniące funkcje kierownicze w tych wyznaniach (np. biskupi w Kościele katolickim). Wymóg posiadania obywatelstwa polskiego znajduje pewne uzasadnienie wobec liderów duszpasterstwa w Wojsku Polskim ${ }^{45}$. Zastrzeżenie członkostwa w gminach wyznaniowych żydowskich dla obywateli polskich zamieszkałych w RP oraz obligatoryjne zaliczenie wszystkich wyznawców islamu w Polsce do MZR należy ocenić jako prawdopodobnie sprzeczne z wolnością uzewnętrzniania religii $\mathrm{w}$ aspekcie kolektywnym. Jednostka posiadająca pełną zdolność do czynności prawnych powinna mieć pełną swobodę tworzenia i przynależności do wspólnot konfesyjnych.

Ograniczenia uprawnień cudzoziemców w dziedzinie pełnienia funkcji kierowniczych, rejestracji związków wyznaniowych, przynależności do gmin wyznaniowych żydowskich, na podstawie kryterium obywatelstwa, czy składania wniosków o rejestrację związków wyznaniowych można także postrzegać jako sprzeczne z zakazem dyskryminacji z jakiejkolwiek przyczyny (art. 32 ust. 2 Konstytucji). Kryterium dyskryminacji jest w świetle opisanych regulacji brak obywatelstwa polskiego. Zakaz pełnienia godności biskupów przez cudzoziemców w Kościele katolickim w Polsce można oceniać jako sprzeczny z konstytucyjną zasadą równouprawnienia kościołów i innych związków wyznaniowych (art. 25 ust. 1). Tylko bowiem Kościół katolicki został w podanym zakresie pozbawiony prawa do swobodnej obsady swej zasadniczej kategorii organów kierowniczych.

W świetle wyżej wskazanych regulacji jest całkiem prawdopodobne uznanie przez Międzynarodowy Trybunał Praw Człowieka w Strasburgu naruszenia przez Polskę art. 9 ust. 1 EKPCz, czyli wolności myśli sumienia i wyznania w wymiarze kolektywnym. Nasze państwo naraża się w szczególności na zarzut naruszenia tzw. autonomii wspól-

Ewangelicko-Metodystyczny w RP, Kościół Chrześcijan Baptystów w RP, Starokatolicki Kościół Mariawitów w RP, Kościół Adwentystów Dnia Siódmego w RP, Kościół Polskokatolicki w RP, Kościół Zielonoświątkowy w RP oraz Związek Gmin Wyznaniowych Żydowskich w RP.

${ }^{45}$ Obecnie w Wojsku Polskim działają: katolicki Ordynariat Polowy WP, Prawosławny Ordynariat Polowy oraz Ewangelickie Duszpasterstwo Wojskowe Kościoła Ewangelicko-Augsburskiego w RP. 
not religijnych. Większą ochronę prawną cudzoziemcom zapewniłoby ratyfikowanie przez Polskę Protokołu nr 12 do EKPCz.

Ograniczenia dotyczące rejestracji związków wyznaniowych należy oceniać także jako sprzeczne z art. 18 Traktatu o funkcjonowaniu Unii Europejskiej, zakazującego dyskryminacji obywateli UE ze względu na przynależność państwową ${ }^{46}$. Zatem ograniczenia tego rodzaju należałoby uznać za uchylone w odniesieniu do obywateli UE z chwilą przystąpienia Polski do tej organizacji.

Dla cudzoziemców potencjalne znaczenie ma fakt, że prawo penitencjarne nie gwarantuje osadzonym diety odpowiadającej normom religijnym, tzn. diety jarskiej, diety koszernej, czy diety halal ${ }^{47}$. W art. 109 §1 ustawy z dnia 6 czerwca 1997 r. - Kodeks karny wykonawczy ${ }^{48}$ stanowi się, że skazany otrzymuje trzy razy dziennie posiłki, o odpowiedniej wartości odżywczej, w tym co najmniej jeden posiłek gorący, z uwzględnieniem w miarę możliwości także wymogów religijnych i kulturowych oraz napój do zaspokajania pragnienia.

Potencjalnie nadmiernie uciążliwe są przewidziane w ustawie z dnia 31 stycznia 1959 r. o cmentarzach i chowaniu zmarłych ${ }^{49}$ wymogi przewozu i wywozu zwłok cudzoziemca za granicę. Konieczność uzyskania zgody odpowiednich polskich i obcych władz sanitarnych ${ }^{50}$ wydaje się zbyteczna w przypadku wywozu prochów ludzkich

${ }^{46}$ Zob. Traktat o funkcjonowaniu Unii Europejskiej, red. nauk. A. Wróbel, t. I, red. D. Miąsik, N. Półtorak, Warszawa 2012, s. 375-376.

${ }^{47}$ Zob. rozporządzenie Ministra Sprawiedliwości z dnia 2 września 2003 r. w sprawie określenia wartości dziennej normy wyżywienia oraz rodzaju diet wydawanych osobom osadzonym w zakładach karnych i aresztach śledczych (Dz. U. Nr 167, poz. 1633 z późn. zm.)

${ }^{48}$ Dz. U. Nr 90, poz. 557 z późn. zm.

${ }^{49}$ Tekst jedn. Dz. U. z 2011 r. Nr 118, poz. 687 z późn. zm.

${ }^{50}$ Zgodnie z art. 14 tej ustawy, transport zwłok lub szczątków ludzkich poza granice Rzeczypospolitej Polskiej, w przypadku, gdy zgon nastąpił na terytorium RP, może nastąpić po uzyskaniu pozwolenia właściwego państwowego powiatowego inspektora sanitarnego. W przypadku przewożenia zwłok i szczątków poza granice Rzeczypospolitej Polskiej pozwolenie, o którym mowa w ust. 1, wydaje się po uprzednim przedłożeniu wymaganych dokumentów właściwej władzy państwa, na którego terytorium mają być one pochowane, jak również państw, przez których terytorium mają być przewożone, stwierdzających brak przeszkód do pochowania lub wwiezienia zwłok lub szczątków na terytorium danego państwa. Przewóz zwłok i szczątków przez terytorium RP może nastąpić po uzyskaniu zaświadczenia wydanego przez polskiego konsula w państwie, z którego przewóz ten ma 
będących finalnym produktem kremacji zwłok. Owe prochy w praktyce są już bowiem całkowicie neutralne dla otoczenia. Niestety, w prawie polskim brak jest kompleksowej regulacji dotyczącej kremacji, przede wszystkim określającej standardy sanitarne i techniczne tego procesu.

W nielicznych przypadkach pierwiastek religijny jest zarazem przesłanką przyznania cudzoziemcom szczególnych uprawnień w Polsce. Ustawa o udzielaniu cudzoziemcom ochrony na terytorium Rzeczpospolitej Polskiej przewiduje nadanie cudzoziemcowi statusu uchodźcy, jeżeli na skutek uzasadnionej obawy przed prześladowaniem w kraju pochodzenia z powodu w szczególności religii nie może on lub nie chce korzystać z ochrony tego. Status uchodźcy nadaje się także małoletniemu dziecku cudzoziemca, który uzyskał status uchodźcy w Polsce, urodzonemu na tym terytorium (art. 13 ust. 1). Należy podkreślić, że na potrzeby wspomnianej ustawy przyjęto szeroką wykładnię pojęcia „religia” (art. 14 ust. 1 pkt 2). Natomiast ustawa o cudzoziemcach dopuszcza możliwość udzielenia cudzoziemcowi zezwolenia na pobyt czasowy, o ile jest duchownym, członkiem zakonu lub osobą pełniącą funkcję religijną w kościele lub związku wyznaniowym, którego status jest uregulowany umową międzynarodową, przepisami obowiązującego na terytorium Rzeczypospolitej Polskiej prawa lub który działa na podstawie wpisu do rejestru kościołów i innych związków wyznaniowych, i jeżeli jego pobyt na terytorium Rzeczypospolitej Polskiej jest związany z pełnioną funkcją lub przygotowaniem do jej pełnienia (art. 187 pkt 3) ${ }^{51}$.

\section{PODSUMOWANIE}

Szczegółowa analiza współczesnego polskiego systemu prawnego wskazuje, że w dziedzinie wolności sumienia i wyznania cudzoziemcy

nastąpić, stwierdzającego brak przeszkód do wwiezienia zwłok i szczątków na terytorium innego państwa.

${ }^{51}$ Warto odnotować, że samo pełnienie funkcji przez cudzoziemca w związku wyznaniowym nie wymaga zezwolenia na pracę, zob. art. 88 ustawy z dnia 20 kwietnia 2004 r. o promocji zatrudnienia i instytucjach rynku pracy (tekst jedn. Dz. U. z 2013 r., poz. 674 z późn. zm.). 
nie posiadają w pełni takich samych uprawnień, co obywatele polscy. Taki stan legitymizuje Konstytucja z 1997 r. dopuszczając możliwość ograniczenia w drodze ustawy konstytucyjnych wolności i praw cudzoziemców w porównaniu z obywatelami polskimi. Zasadę egalitaryzmu $\mathrm{w}$ traktowaniu obu tych grup wyrażają natomiast ratyfikowane lub podpisane przez Polskę najważniejsze akty prawa międzynarodowego, dotyczące wolności sumienia i wyznania. Możliwie optymalny poziom gwarancji równego traktowania cudzoziemców z obywatelami w sferze wspomnianej wolności zapewni jednak dopiero ratyfikacja Protokołu nr 12 do Konwencji z 1950 r. Wskazane jest również przystąpienie Rzeczypospolitej Polskiej do najważniejszych aktów prawnych zabezpieczających status bezpaństwowców (z 1954 r. i z 1961 r.).

Z kolei przewidziany przez Konkordat z 1993 r. wymóg posiadania przez biskupów w Polsce rodzimego obywatelstwa należy ocenić krytycznie jako przejaw postrzegania hierarchii Kościoła katolickiego w kategoriach politycznych, a zarazem przejaw dyskryminacji tego wyznania.

Powyższe zarzuty, uzupełnione także zarzutem naruszenia zasady niezależności i autonomii właściwych konfesji, czy nawet naruszeniem wolności sumienia i wyznania cudzoziemców, można postawić wobec polskiego ustawodawstwa uzależniającego pełnienie funkcji kierowniczych w niektórych związkach wyznaniowych od posiadania obywatelstwa polskiego. Są to ograniczenia znamienne dla systemu powiązania państwa ze związkami wyznaniowymi, systemu nieadekwatnego do modelu stosunków wyznaniowych zawartego w Konstytucji RP z 1997 r. Za bodaj najdalej idące ograniczenia swobód religijnych cudzoziemców wypada uznać zakaz ich członkostwa w gminach wyznaniowych żydowskich, a przede wszystkim niemożność wystąpienia z wnioskiem o rejestrację związku wyznaniowego. Wskazane ograniczenia ustawowe zasługują na jak najszybsze zniesienie. Nie odpowiadają one realiom stosunków społecznych, szczególnie w aspekcie międzynarodowym. Ich utrzymanie grozi bowiem porażką Polski przed międzynarodowymi organami ochrony wolności i praw człowieka.

Ograniczenia swobody cudzoziemców w sprawach religijnych mają także charakter przedmiotowy i niedyskryminacyjny, tzn. dotyczą ich na równi z obywatelami polskimi. Wynikają one zwłaszcza z uwarunko- 
wań społeczno-politycznych współczesnej Polski. Jesteśmy państwem wciąż dość homogenicznym pod względem etnicznym i wyznaniowym. Czynnik ten nieprzerwanie oddziałuje na polskie ustawodawstwo po roku 1989. Zarazem funkcji liberalizującej w zakresie szeroko rozumianej wolności sumienia i wyznania nie spełniło dotychczas wyraźnie ani orzecznictwo sądów powszechnych i Sądu Najwyższego, ani tym bardziej Trybunału Konstytucyjnego.

\section{BIBLIOGRAFIA}

Borecki P., Prawo wyznaniowe w świetle Konstytucji Rzeczypospolitej Polskiej z 1997 r. Warszawa 2013.

Borecki P., Status prawny osób bezwyznaniowych w Polsce, „Państwo i Prawo” 2007, z. 4.

Borecki P., Zasada równouprawnienia wyznań w prawie polskim, „Studia z Prawa Wyznaniowego" 2007, t. 10.

Borecki P., Pietrzak M., Glosa do wyroku Trybunału Konstytucyjnego z 2 IV 2003 r., K 13/02, „Państwo i Prawo” 2003, z. 8.

Brzozowski W., Glosa do wyroku Trybunatu Konstytucyjnego z 14 XII 2009, K 55/07, „Państwo i Prawo” 2010, z. 5

Góralczyk W., Sawicki S., Prawo międzynarodowe publiczne w zarysie, Warszawa 2013.

Góralski W., Pieńdyk A., Zasada niezależności i autonomii Państwa i Kościoła w konkordacie Polskim z 1993 roku, Warszawa 2000.

Konwencja o Ochronie Praw Człowieka i Podstawowych Wolności, t. 1, Komentarz do artykułów 1-18, red. L. Garlicki, Warszawa 2010.

Krukowski J., Kościót i Państwo. Podstawy relacji prawnych, Lublin 2000.

Potz M., Granice wolności religijnej. Kwestie wolności sumienia $i$ wyznania oraz stosunku państwa do religii w Stanach Zjednoczonych Ameryki, Wrocław 2008.

Sarnecki P., Prawo o stowarzyszeniach. Komentarz, Kraków 2007.

Szymanek J., Konstytucyjna zasada równouprawnienia kościołów i innych zwiazków wyznaniowych, „Studia Prawnicze” [PAN] 2009, z. 1-2.

Traktat o funkcjonowaniu Unii Europejskiej, red. nauk. A. Wróbel, t. I, red.

D. Miąsik, N. Półtorak, Warszawa 2012.

Wisłocki J., Konkordat polski 1993. Tak czy nie?, Poznań 1993. 
Zieliński T.J., Ustawa o gwarancjach wolności sumienia $i$ wyznania z 1989 r. jako ,magna charta” swobód światopogladowych w Polsce, w: Prawo wyznaniowe w Polsce (1989-2009). Analizy - dyskusje - postulaty, red. D. Walencik, Katowice - Bielsko-Biała 2009.

\section{THE FREEDOM OF CONSCIENCE AND RELIGION \\ OF FOREIGNERS IN POLISH LAW}

\section{Summary}

According to Polish law foreigners do not have fully the same privileges as Polish citizens in the field of freedom of conscience and religion. The Constitution of 1997 allows the limitation of constitutional rights and freedoms of foreigners in comparison with Polish citizens by law. On the other hand, the principle of egalitarianism in the treatment of both groups is expressed in the most important acts of international law concerning the freedom of conscience and religion ratified or signed by Polish authorities.

Nevertheless, the best guarantee of equal treatment of foreigners and citizens in the area of that freedom could only be fully provided due to the ratification of Protocol No. 12 to the Convention for the Protection of Human Rights and Fundamental Freedoms of 1950. Moreover, Polish accession to the most vital legal acts protecting the status of stateless persons (from 1954 and 1961 ) is highly recommended Consequently, the requirement of having native citizenship by Polish bishops provided by the Polish Concordat in 1993 should be assessed critically as the manifestation of the perception of the Catholic Church hierarchy in political terms as well as the discrimination of the Catholic religion.

The above mentioned allegations, which can be supplemented with the charges of the breach of the principle of independence and autonomy of the relevant confessions, or even the violation of freedom of conscience and religion of the foreigners, can be put against the provisions of the Polish legislation, which conditions holding managerial functions in some religious associations on having Polish citizenship. There are significant limitations to the system of relations between the State and religious associations.

The most far-reaching restriction of the religious freedoms concerning foreigners seems to be the ban on their membership in the Jewish religious 
communities, and above all, the lack of an opportunity to apply for the registration of a religious association.

All of the above mentioned legislative restrictions should be immediately abolished as they do not correspond with the reality of social relations, particularly in an international context. Their maintenance might cause a failure of Polish authorities in case they were sued by the international human rights and freedoms organizations.

Additionally, the restrictions of freedom in religious matters concerning foreigners also have objective and non-discriminatory nature, ie. they are the same as the restrictions concerning Polish citizens. In particular, they derive from socio-political condition of contemporary Poland. Unfortunately, our country is still ethnically and religiously homogenical. This factor continuously affects Polish legislation after the year1989. At the same time, neither the case law of ordinary courts nor the case law of the Supreme Court or even the Constitutional Court have fulfilled the liberalizing function in the broadest sense of freedom of conscience and religion.

Ttumaczenie własne autora

Key words: freedom of conscience and religion, foreigners, discrimination, constitution, concordat

Słowa kluczowe: wolność sumienia i religii, cudzoziemcy, dyskryminacja, Konstytucja RP, konkordat 